\title{
Association between the IL-7Ra gene polymorphisms of rs6897932 and rs987106 with atopic diseases: A case-control design
}

Parnian Zolfaghari Baghbadorani

Isfahan University of Medical Sciences

Amirmasoud Rayati Damavandi ( $\square$ amirmasoud.r@yahoo.com )

Tehran University of Medical Sciences School of Medicine

Bahareh Kardedeh

Kermanshah University of Medical Sciences

Samaneh Mostafavi

Isfahan University of Medical Sciences

Rasoul Salehi

Isfahan University of Medical Sciences

Mohammad Kazemi

Isfahan University of Medical Sciences

Ramin Ghasemi

Isfahan University of Medical Sciences

Nahid Eskandari

Isfahan University of Medical Sciences

Farshid Fathi

Isfahan University of Medical Sciences

\section{Research Article}

Keywords:

Posted Date: February 14th, 2022

DOI: https://doi.org/10.21203/rs.3.rs-1330371/v1

License: (c) (i) This work is licensed under a Creative Commons Attribution 4.0 International License.

Read Full License 


\section{Abstract \\ Background}

Atopy is used to describe the genetic tendency to IgE-mediated responses. Many factors contribute to predisposing individuals to atopy, including cytokines. IL-7 is a cytokine that mediates hypersensitivity responses and proliferation of $T$ cells and has a polymorphic gene for its receptor (CD127). These different alleles may affect the signaling cascade or alter the production of inflammatory cytokines, which may exacerbate atopic conditions, including asthma and allergy.

\section{Objective}

Primary objective of our study aimed to explore the linkage between IL-7Ra gene polymorphism at the SNP of rs6897932 and the risk of atopic diseases. Evaluating the association of IL-7Ra SNP of rs987106 and also serum levels of IL-7 with the risk of atopy are among the secondary objectives.

\section{Methods}

To seek possible relations of SNPs rs6897932 and rs987106 with the risk of atopy, we recruited 101 atopic patients and 201 sex-age matched healthy controls from Iranian ethnicity and used the data for evaluation.

\section{Results}

Statistical analysis revealed that the T allele variant of IL-7Ra gene at the SNP of rs6897932 is more prevalent among the atopic patients $(53.5 \%)$ than in the controls $(26.9 \%)$ and have a considerable association with the disease ( $p<0.0001$, OR: 3.13 (95\% Cl- 1.90 to 5.16$)$ ). Also, the higher frequency of T allele variant of rs987106 in atopic patients $(64.4 \%)$ versus control $(31.3 \%)$ was associated with around a 4 -fold increase in the risk of atopy ( $p<0.0001$, OR: 3.95 (95\% Cl- 2.39 to 6.55$)$ ). However, there was no significant association between IL-7 serum levels and atopic disorders $(p>0.05)$.

\section{Conclusion}

Our study in the Iranian population may support that T allele variants of rs6897932 and rs987106 are risk factors for atopy. However, serum levels of IL-7 were not significantly associated with a heightened risk of atopy.

\section{Introduction:}


The immune system projects a complex interplay between the host's genetic composition and environmental factors. Any irregularities, even subtle ones, could lead to out of proportion immune responses. Among defects, allergies and hypersensitivities are increasingly prevalent in both developed and developing countries, with limited therapeutic tools that mainly focus on the relief of the symptoms. One of the common inherent hypersensitivities is atopy and is a condition in which a tendency to immunoglobulin $\mathrm{E}$ ( $\mathrm{IgE}$ ) overproduction against the small amounts of foreign antigens is present (1). Atopic diseases are the clinical presentations of the atopy and encompass allergic rhinitis, asthma, food allergies, and atopic dermatitis. Despite being related terms, atopy and allergy are two distinct entities. The term allergy refers to the development of symptoms upon contact with the allergen of which there is an IgE-specific response previously, while individuals with atopy may remain clinically silent in the form of asymptomatic sensitization. According to recent estimates, the highest rates of allergic diseases worldwide belong to asthma, food allergies, drug allergies, and allergic rhinitis (2).

The various lineage of cells contribute to the pathophysiology of atopy and allergic diseases; however, there is a central role for T helper 2 (Th2) lymphocyte and its related cytokines, including Interleukin (IL)-4, IL-5, and IL-13. These elements provoke a cascade of sensitization mediated by the production of IgE. Induction of Th2 transformation to the naïve T cells initiates with allergen recognition by antigenpresenting cells (APCs) that migrate to the nearby lymph nodes. Th2 cells then activate the B cells responsible for differentiation into the allergen-specific IgE-producing plasma cells. The tissue-resident mast cells and basophils receive allergen-specific IgE by their high-affinity IgE receptor labeled FceRI. By the next entry of the allergen, this machinery responds by producing numerous mediators, including histamine, prostaglandins, leukotrienes, chemokines, reactive oxygen species (ROS), and recruitment eosinophils with their tissue-destructing granules. These reactions contribute to allergic manifestations, including tissue edema, vasodilation, and bronchospasm (3).

While inflammatory cells are the actors of the hypersensitivity responses, the cytokines released by these cells have gained attraction in recent studies as they might influence vulnerability to atopic diseases. Moreover, the solid hereditary background has been attributed to atopic diseases, including atopic dermatitis and allergic rhinitis $(4,5)$. Thus, exploring the polymorphisms in genes modulating cytokine expression, specifically interleukins, is essential for the surveillance of susceptible individuals.

The mainstream studies on the association of Interleukins gene polymorphisms and atopy are around direct mediators, including IL-4 and IL-13 (6-12). However, other alterations of genes expressing ILs and their receptors have been investigated in parallel.

One of the ILs responsible for proliferation and regulating the homeostasis of T cells is IL-7 (13). It is secreted by various non-hematopoietic cells, including keratinocytes, epithelial cells in the intestine, prostate, and thymus, and dendritic cells (DCs) (14-16). IL-7 is essential for maintaining the survival of both naïve and mature $T$ cells through its receptor, IL-7R, which has a common chain with thymic stromal lymphopoietin (TSLP) (17). These imply that IL-7 may have a regulatory effect on the central orchestrator of atopy, the Th2 cell. Thus, seeking the SNPs and polymorphisms of the IL-7 and IL-7R genes seems 
worthwhile $(18,19)$. Moreover, the possible role of IL-7 in atopy was suggested when the results of the allergen patch test showed that the expression of IL-7 messenger RNA was high in atopic dermatitis patients $(20,21)$.

In this study, we aimed to evaluate the genetic associations of IL7R gene SNPs and atopy in addition to the measurement of IL-7 serum levels in atopic patients.

\section{Materials And Methods: \\ 2.1 Study population:}

This case-control study enrolled 101 atopic patients confirmed for asthma and allergic disorders by a physician according to the AAAAI/ACAAI Joint Task Force (JTF) practice parameters guidelines (22), and all of them had a moderate type of allergy. Atopic diseases such as asthma, allergic rhinitis, and eczema are characterized by an elevated and prolonged IgE antibody response after exposure to an allergen. Also, 201 sex-age matched healthy people participated in the study. The control group was selected randomly without any history of allergy, autoimmunity, or malignancy. All Study participants were of Persian ethnicity and selected from the Isfahan province of Iran. The work was conducted from May 2018 to December 2019. The study was approved by the ethical committee of Isfahan University of Medical Sciences (number 393046) and performed according to the declaration of Helsinki. Informed consent was obtained from all participants before entering the study. Additionally, for serum levels of IL-7, 37 atopic patients and 36 healthy individuals were assessed by ELISA.

\subsection{Sample preparation and DNA extraction:}

After completing the questionnaire and the informed consent, $5 \mathrm{ml}$ EDTA-treated whole blood samples were obtained from all the patients and controls. Using red blood cell (RBC) lysis buffer, white blood cells (WBCs) were segregated from whole blood samples. The genomic DNA was extracted from samples using the Genomic DNA Extraction Kit (Genet Bio Korean Company) based on the manufacturer's brief instruction. The purity and quality of DNA were determined using a spectrophotometer (NanoDrop 8000 spectrophotometer, Thermo Scientific, Wilmington, USA). Extracted DNAs were frozen in $-85^{\circ} \mathrm{C}$ until all samples were collected for the subsequent tests. Sera, however, were collected in other tubes by centrifuging the clot at $2400 \mathrm{rpm}$ for 10 minutes.

\subsection{High-resolution melting PCR (HRM):}

To explore IL-7R gene polymorphisms, we conducted High-resolution melting PCR (HRM-PCR). All the primers with $50 \% \mathrm{GC}$ content, $58.4^{\circ} \mathrm{C}$ temperature, without complementary ends, and standard length between 18 to 30 base pairs have been designed precisely according to scientific principles using the Primer3 software.

The assay was performed using the Rotor-Gene 6000- Real-Time PCR System (Corbett, Mortlake, NSW, Australia) with a total reaction volume of $10 \mu \mathrm{L}$; we added $5 \mu \mathrm{L} 2 \mathrm{X}$ Solise Biodyne HRM kit (Solise 
Biodyne Estonia Company), $1 \mu \mathrm{L}$ of each Forward and Reverse primers $1 \mu \mathrm{L}$ DNA and $2 \mu \mathrm{L}$ DW.

Temperature cycling parameters were: 1) For initial activation, $95{ }^{\circ} \mathrm{C}$ for 15 minutes, followed by 35 cycles of denaturation in $95^{\circ} \mathrm{C}$ for 15 seconds, 2) For annealing, $60{ }^{\circ} \mathrm{C}$ for 15 seconds, and 3) For extension 72 ${ }^{\circ} \mathrm{C}$ for 20 seconds. Finally melting curve was done at $60-95^{\circ} \mathrm{C}$. Other information about the PCR reaction and primers' sequences is illustrated in Table 1 and Table 2.

Table 1

Primer sequences of IL-7Ra gene SNPs at rs987106 and 6897932.

\begin{tabular}{|lc|}
\hline \multicolumn{2}{|l|}{ IL-7Ra (rs:987106) } \\
\hline Reverse primer $\quad$ 5' TGGTCACCCACCTAATTGTG 3' \\
\hline Forward primer $\quad$ 5' GGAGACTGGGCCATACGATA 3' \\
\hline IL-7Ra (rs:6897932) \\
\hline Reverse primer & 5'CCC ACA CAA TCA CCC TCT TTA T 3' \\
\hline Forward primer & 5'CTT CAA GTG GCA GAT GCT CTG 3' \\
\hline
\end{tabular}

Table 2

Temperature protocol for Corbett instrument HRM PCR

\begin{tabular}{|lll|}
\hline Step & $\begin{array}{l}\text { Temperature (o } \\
\mathrm{C})\end{array}$ & Time \\
\hline $\begin{array}{l}\text { Initial } \\
\text { Activation }\end{array}$ & $95^{\circ} \mathrm{C}$ & $15 \mathrm{mins}$ \\
\hline Denaturation & $95^{\circ} \mathrm{C}$ & $15 \mathrm{sec}$. \\
Annealing & $60^{\circ} \mathrm{C}$ & $20 \mathrm{sec}$. \\
\hline Extension & $72^{\circ} \mathrm{C}$ & $20 \mathrm{sec}$. \\
\hline Melt & $60^{\circ} \mathrm{C}-95^{\circ} \mathrm{C}$ & $\begin{array}{l}90 \mathrm{sec} . \text { of pre melt on the first step and } 2 \mathrm{sec} \text {. for each step } \\
\text { afterward }\end{array}$ \\
\hline
\end{tabular}

\subsection{IL-7 serum level measurement by ELISA:}

Peripheral blood samples were clotted and then centrifuged (for 10 mins, $2400 \times \mathrm{g}$ ). Serums were frozen immediately at $-20^{\circ}$ for 2 hours, then; at $-85 \mathrm{C}$ until all samples were collected. According to the manufacturer's instruction, serum levels of IL-7 were quantified using a commercial ELISA kit (Boster Biological Technology, USA).

\subsection{Statistical analysis:}

Statistical analysis was performed by STATA 14.0 software (StataCorp. 2015. Stata Statistical Software: Release 14. College Station, TX: StataCorp LP.). Kolmogorov-Smirnov Z-test was conducted for normality testing of data distribution. The genotype and allele frequencies for deviation from the Hardy-Weinberg 
equilibrium (HWE) proportions were tested by using a chi-squared test (the genotype distribution for HWE was considered significant at $(p<0.05)$ ). Paired samples t-test (matched groups) was used to evaluate the mean of age and serum levels of IL-7 in the atopic patients and control group. These are a collection of statistical tests used in the analysis of stratified categorical data. Significant allelic and genotypic associations were calculated by Pearson $\chi 2$ and Fisher's exact test alongside evaluation of the odds ratio (OR) and $95 \%$ confidence intervals $(\mathrm{Cl})$. The P-values $<0.05$ were considered statistically significant. We followed the interpretation zones for the effect size of odds ratio (OR): 1) Small for 1.22 to $1.85,2$ ) Medium for 1.86 to 2.99 , and 3) Large for above 3.00 values (23).

\section{Results:}

In this study, IL-7Ra gene polymorphisms in SNPs of rs6897932 and rs987106 were probed in 101 patients and 201 individuals in control group along with IL-7 serum levels in a total of 302 subjects. The patients' group consisted of 101 individuals with 37 (36.6\%) males and $64(63.4 \%)$ females by the mean age \pm SD of $32 \pm 12.1$ years. The types of disease were allergic asthma in $58(57.4 \%)$ and allergic rhinitis in $43(42.6 \%)$ individuals. Also, the sex-age matched controls group included $75(37.5 \%)$ males and 126 $(62.5 \%)$ females, with the mean age \pm SD of $32 \pm 12.5$ years. All the patients had allergic disorders in different ways from birth, and all of them had a family history of atopy. The total serum IgE concentration $(\mathrm{IU} / \mathrm{mL})$ was assessed for 302 subjects, and the average total IgE was found higher in the patients $(2651.7 \pm 166.3 \mathrm{IU} / \mathrm{mL})$ than in the controls $(146.1 \pm 22.4 \mathrm{IU} / \mathrm{mL})$. The demographic characteristics of both patients and control groups, including sex, age, atopic status, IgE level, and smoke exposure, are illustrated in Table 3. 
Table 3

Demographic characteristics of participants.

\begin{tabular}{|c|c|c|c|}
\hline Characteristics & Patients group $(n=101)$ & $\begin{array}{l}\text { Control group } \\
(\mathrm{n}=201)\end{array}$ & $\begin{array}{l}\text { p- } \\
\text { value }\end{array}$ \\
\hline Years of age (Mean \pm SD) & $32 \pm 12.1$ & $32 \pm 12.5$ & $0.63^{*}$ \\
\hline Gender (n, \%) & $37(36.6 \%)$ & 75 (37.5\%) & $0.73^{\#}$ \\
\hline Male & $64(63.4 \%)$ & $126(62.5 \%)$ & \\
\hline \multicolumn{4}{|l|}{ Female } \\
\hline \multirow[t]{2}{*}{ Allergy type } & Allergic asthma: 58 (57.4\%) & \multirow[t]{2}{*}{-- } & \\
\hline & Allergic rhinitis: 43 (42.6\%) & & \\
\hline $\mathrm{BMI}\left(\mathrm{Kg} / \mathrm{m}^{2}\right)$ & $23.2 \pm 1.9$ & $23.7 \pm 2.1$ & \\
\hline Total IgE serum levels (IU/mL) & $2651.7 \pm 166.3$ & $146.1 \pm 22.4$ & \\
\hline WBC count & $17.5 \pm 3.5$ & $7.5 \pm 3.1$ & \\
\hline \multicolumn{4}{|l|}{$\left(10^{3} / \mu \mathrm{l}\right.$, Mean $\left.\pm \mathrm{SD}\right)$} \\
\hline Eosinophil count & $6.2 \pm 1.8$ & $0.6 \pm 0.2$ & \\
\hline \multicolumn{4}{|l|}{$\left(10^{3} / \mu \mathrm{l}\right.$, Mean $\left.\pm \mathrm{SD}\right)$} \\
\hline $\begin{array}{l}\text { Mast cell count }\left(10^{3} / \mu \mathrm{l}, \text { Mean } \pm\right. \\
\text { SD) }\end{array}$ & $2.1 \pm 0.8$ & -- - & \\
\hline Duration of Asthma (years) & $\begin{array}{l}8.4 \pm 3.2 \text { (in asthma } \\
\text { subgroup) }\end{array}$ & -_- & \\
\hline \multirow[t]{2}{*}{ Family History } & Yes: 29 (28.7\%) & Yes: 4 (1.9\%) & \\
\hline & No: 72 (71.3\%) & No: 197 (98.1\%) & \\
\hline Smoking & Yes: 41 (40.6\%) & Yes: 86 (42.7\%) & \\
\hline (Current or history) & No: 60 (59.4\%) & No: $115(57.3 \%)$ & \\
\hline \multirow[t]{2}{*}{ COPD } & Yes: 18 (17.9\%) & Yes: 3 (1.5\%) & \\
\hline & No: 83 (82.1\%) & No: 198 (98.5\%) & \\
\hline \multicolumn{4}{|l|}{ *: Calculated using paired t-test. } \\
\hline \multicolumn{4}{|c|}{ \#: Calculated using Pearson's chi-squared test. } \\
\hline \multicolumn{4}{|c|}{$\begin{array}{l}\text { SD: Standard Deviation, BMI: Body Mass Index, IU: International Unit, mL: Milli Liter, } \mu \text { l: MicroLiter, } \\
\text { WBC: White Blood Cells, COPD: Chronic Obstructive Pulmonary Disease }\end{array}$} \\
\hline
\end{tabular}




\subsection{IL-7Ra polymorphism rs6897932 C>T and its correlation with risk of atopy:}

Our results showed that the CC genotype is the most frequent in both patients (46.5\%) and control (73.1\%) groups. Statistical analysis for the genotypic frequencies in IL-7Ra gene revealed a difference between patients and the control group $(p<0.001)$.

Our analysis of the allelic frequencies for IL-7Ra rs6897932 SNP indicated that the mutant T allele of IL7Ra was more prevalent among the atopic patients (53.5\%) than in the controls (26.9\%) and had a significant and considerable association with the disease ( $p<0.0001$, OR: 3.13 (95\% Cl- 1.90 to 5.16)). Additionally, there was no association between IL-7Ra polymorphism rs6897932 C>T and demographic characteristics $(p>0.05)$ Table 4.

Table 4

Distribution of genotypes and alleles for SNP rs6897932 among patients and control groups.

\begin{tabular}{|c|c|c|c|c|}
\hline Genotype (n, \%) & Patients group & Control group & Odds Ratio (OR) * & $p_{\text {value }}{ }^{\dagger}$ \\
\hline $\mathrm{CC}$ & 47 (46.5\%) & $147(73.1 \%)$ & - & \multirow[t]{3}{*}{$<0.001$} \\
\hline CT & $31(30.7 \%)$ & $54(26.9 \%)$ & - & \\
\hline TT & $23(22.8 \%)$ & $0(0.0 \%)$ & - & \\
\hline \multicolumn{5}{|l|}{ Allele (n, \%) } \\
\hline C & $47(46.5 \%)$ & $147(73.1 \%)$ & \multirow[t]{2}{*}{$3.13(1.90-5.16)$} & \multirow[t]{2}{*}{$<0.0001$} \\
\hline $\mathrm{T}$ & $54(53.5 \%)$ & $54(26.9 \%)$ & & \\
\hline
\end{tabular}

\subsection{Association of IL-7Ra gene polymorphism of rs987106 A $>$ T with risk of atopy:}

The evaluation of allele frequency of SNP rs 987106 revealed that T allele prevalence was considerably superior in the patients' group $(64.4 \%)$ compared to the control $(31.7 \%)(p<0.05)$. In parallel, the TT genotype was associated with the elevated risk of atopy by around 4-fold ( $p<0.0001$, OR: 3.95 (95\% Cl2.39 to 6.55$)$ ). This could be translated to a higher risk of atopy for individuals carrying the $T$ allele at the SNP rs987106 for IL-7Ra gene Table 5. 
Table 5

Distribution of genotypes and alleles for SNP rs987106 among patients and control groups

\begin{tabular}{|lllll|}
\hline Genotype $(n, \%)$ & Patients group & Control group & Odds Ratio (OR) * $^{*}$ p value $^{\dagger}$ & $<0.001$ \\
\hline AA & $36(35.6 \%)$ & $138(68.7 \%)$ & - & \\
AT & $40(39.6 \%)$ & $40(19.9 \%)$ & - & \\
\hline TT & $25(24.8 \%)$ & $23(11.4 \%)$ & - & $<0.0001$ \\
Allele $(n, \%)$ & & & & \\
\hline T & $65(64.4 \%)$ & $63(31.3 \%)$ & $3.95(2.39-6.55)$ & \\
A & $36(35.6 \%)$ & $138(68.7 \%)$ & & \\
*: $95 \%$ Cl calculated using Woolf method. & & \\
t: Calculated using Pearson's chi-squared test. & & \\
\hline
\end{tabular}

\subsection{IL-7 serum levels assessment in atopy:}

The serum levels of IL-7 in the atopic patients and controls were determined by the ELISA method. Accordingly, there were no significant differences in the serum levels of this pro-inflammatory cytokine in the patients (mean \pm SD of $341.15 \pm 65.7 \mathrm{pg} / \mathrm{ml})$ and controls $(323.4 \pm 65.1 \mathrm{pg} / \mathrm{ml})(p>0.05)$. Also, statistical analysis showed no association between IL-7serum level and demographic characterizes ( $p>$ 0.05).

\section{Discussion:}

The multifactorial nature of atopic diseases is bounded by the influential role of inflammatory mediators, including interleukins. The genetic backbone of atopy directs the exploration of polymorphisms among susceptible individuals. Previous studies put effort into demonstrating the relationship between various ILs or their receptors gene polymorphisms and atopic diseases. Multiple SNPs at IL-4 and IL-13 genes and their receptors as the established mediators of atopy have been investigated, while some cytokines, including IL-7, have recently gained attention. In the study of Qurashi et al., the genotypes of I50V and Q576R in the IL-4R gene were considered risk factors toward atopy (6). Also, in another study, the serum level of IL-4 and SNPs of 590C/T and 589C/T in the IL-4 gene were associated with the risk of atopic dermatitis in children (24). These data are consistent with the meta-analysis conducted by Liang et al. about IL-4 polymorphisms and susceptibility to atopic dermatitis (25).

Regarding IL-13 SNPs, similar efforts have shown the association between specific polymorphisms and the risk of atopy (26-28). In addition to prominent directors, there are some newly probed cytokines in gene polymorphisms and atopic conditions, including IL-6, 7, 10, 18, 27, 31, 33. Among these, IL-7 has a unique position due to sharing various features with TSLP, which has a critical role in Th2-mediated allergic responses. 
Previous studies found the relationship between IL-7Ra gene polymorphisms at SNPs of rs689732 and rs987106 and atopic conditions $(19,29)$, and our analysis provided the evidence that the T allele variants of the IL-7Ra gene in SNP rs6897932 and SNP rs987106 are associated with atopic diseases while no linkage was detected between IL-7 serum levels and the risk of the disease. Furthermore, patient subjects tended to have lower $C$ allele phenotype frequency for the IL-7Ra gene for rs9897932 SNP and showed high IgE, Eosinophils, and Basophils levels compared with control, an essential function of factors in allergy and asthma.

Overexpression of IL-7 leads to marked lymphoproliferation in the skin, as shown by experiments in transgenic mice (30). Recent studies showed that IL-7 could prime innate type 2 lymphocytes in food allergic patients (31). There is also evidence of a potential IL-7 role in eosinophilia and hemostasis of allergen-specific memory T cells in airways $(32,33)$. However, we did not observe significant differences between serum levels of IL-7 or its receptor in the case compared with controls, which may suppose that high serum levels of this pro-inflammatory cytokine may not have a remarkable role in disease onset.

The T/C mutation at IL-7Ra SNP rs9897932 leads to the amino acid exchange that brings about alterations in IL-7Ra conformation, which affects the signaling cascade of IL-7 (18). With the genetic polymorphisms of IL-7R and the role of IL-7 in autoimmune disease susceptibility (34), this would be reasonable if we imply that this gene variation may affect TSLP function as well, which is highly associated with allergy and asthma exacerbation because IL-7R is shared between these two cytokines (35). Moreover, the therapeutic role of blocking IL-7R is documented in a recent study by Mai et al. that targeted IL-7Ra by anti CD127 monoclonal antibody (mAb), resulting in marked resolution of airway inflammation in mice (36). Together, these data indicate the possible role of IL-7 and IL-7R in both atopic conditions and complications of allergic responses while exhibiting promising results in identifying vulnerable ones based on their polymorphisms.

Despite the associations articulated in this study, it has several limitations, such as inadequate sample size and confining to one ethnicity. Furthermore, the function of TSLP as an IL-7 like cytokine might interfere with the phenotype of IL-7 SNPs; thus, it might be reasonable to investigate SNPs at the TSLP gene alongside IL-7 and changes in TSLP functions in individuals with specific IL-7/IL-7R gene polymorphisms. Nevertheless, the function of IL-7 and the association of its receptor polymorphism in atopy remains to be more elucidated. Further studies are required to shed light on the other potential SNPs at IL-7 or IL-7R and their role in atopic diseases.

\section{Abbreviations}

\section{ELISA}

Enzyme-linked immunosorbent assay

\section{HRM}

High resolutions melt

IgE 
Immunoglobulin E

IL

Interleukin

PCR

Polymerase chain reaction

SNP

Single nucleotide polymorphism

Th

T helper

\section{Declarations}

\section{Ethics approval and consent to participate:}

This study was approved by the ethical committee of Isfahan University of Medical Sciences with the ethical code of 393046 in alignment with the 1964 Helsinki declaration. The informed consent has been obtained from all participants in writing.

\section{Consent for publication:}

Not applicable.

\section{Availability of data and materials:}

The data used in this study are available on request from the corresponding author, upon reasonable request.

\section{Competing interests:}

The authors do not declare a conflict of interests.

\section{Funding:}

This study was financially supported by Isfahan University of Medical Sciences with the grant number of 393046.

\section{Authors' contribution:}

AR, RS, and FF were the principal investigators of the study. AR, RS, FF, and MGH were included in preparing the concept and design. MGH and BS revisited the manuscript and critically evaluated the intellectual contents. All authors participated in preparing the final draft of the manuscript, revised the manuscript, and critically assessed the academic content. All authors have read and approved the manuscript and confirmed the accuracy or integrity of any part of the work. 


\section{Acknowledgments:}

The authors thank all individuals who participated in this study.

\section{References}

1. Thomsen SF. Epidemiology and natural history of atopic diseases. Eur Clin Respiratory J. 2015;2(1):24642.

2. Pawankar R. Allergic diseases and asthma: a global public health concern and a call to action. World Allergy Organ J. 2014;7(1):12.

3. Komlósi Zl, van de Veen W, Kovács N, Szűcs G, Sokolowska M, O'Mahony L, et al. Cellular and molecular mechanisms of allergic asthma. Molecular aspects of medicine. 2021:100995.

4. Thomsen SF, Ulrik CS, Kyvik KO, Hjelmborg J, Skadhauge LR, Steffensen I, et al. Importance of genetic factors in the etiology of atopic dermatitis: a twin study. Allergy and asthma proceedings. 2007;28(5):535-9.

5. Thomsen SF, Ulrik CS, Kyvik KO, von Bornemann Hjelmborg J, Skadhauge LR, Steffensen I, et al. Genetic and environmental contributions to hay fever among young adult twins. Respir Med. 2006;100(12):2177-82.

6. Qurashi TA, Bhat GA, Khan MS, Rasool R, Sameen F, Hassan I, et al. Interleukin 4 and Interleukin 4 receptor alpha gene variants and risk of atopy - A case control study based assessment. Clin Immunol (Orlando Fla). 2021;229:108783.

7. Bottema RW, Reijmerink NE, Kerkhof M, Koppelman GH, Stelma FF, Gerritsen J, et al. Interleukin 13, CD14, pet and tobacco smoke influence atopy in three Dutch cohorts: the allergenic study. Eur Respir J. 2008;32(3):593-602.

8. Konstantinidis AK, Barton SJ, Sayers I, Yang IA, Lordan JL, Rorke S, et al. Genetic association studies of interleukin-13 receptor alpha1 subunit gene polymorphisms in asthma and atopy. Eur Respir J. 2007;30(1):40-7.

9. Woitsch B, Carr D, Stachel D, Schmid I, Weiland SK, Fritzsch C, et al. A comprehensive analysis of interleukin-4 receptor polymorphisms and their association with atopy and IgE regulation in childhood. Int Arch Allergy Immunol. 2004;135(4):319-24.

10. Hummelshoj T, Bodtger U, Datta P, Malling HJ, Oturai A, Poulsen LK, et al. Association between an interleukin-13 promoter polymorphism and atopy. Eur $\mathrm{J}$ immunogenetics: official $\mathrm{J} \mathrm{Br} \mathrm{Soc}$ Histocompatibility Immunogenet. 2003;30(5):355-9.

11. Beghé B, Barton S, Rorke S, Peng Q, Sayers I, Gaunt T, et al. Polymorphisms in the interleukin-4 and interleukin-4 receptor alpha chain genes confer susceptibility to asthma and atopy in a Caucasian population. Clin experimental allergy: J Br Soc Allergy Clin Immunol. 2003;33(8):1111-7.

12. Howard TD, Whittaker PA, Zaiman AL, Koppelman GH, Xu J, Hanley MT, et al. Identification and association of polymorphisms in the interleukin-13 gene with asthma and atopy in a Dutch population. Am J Respir Cell Mol Biol. 2001;25(3):377-84. 
13. Jiang Q, Li WQ, Aiello FB, Mazzucchelli R, Asefa B, Khaled AR, et al. Cell biology of IL-7, a key lymphotrophin. Cytokine Growth Factor Rev. 2005;16(4):513-33.

14. Mazzucchelli RI, Warming S, Lawrence SM, Ishii M, Abshari M, Washington AV, et al. Visualization and identification of IL-7 producing cells in reporter mice. PLoS ONE. 2009;4(11):e7637.

15. Di Carlo E, D'Antuono T, Pompa P, Giuliani R, Rosini S, Stuppia L, et al. The lack of epithelial interleukin-7 and BAFF/BLyS gene expression in prostate cancer as a possible mechanism of tumor escape from immunosurveillance. Clin cancer research: official J Am Association Cancer Res. 2009;15(9):2979-87.

16. Guimond M, Veenstra RG, Grindler DJ, Zhang H, Cui Y, Murphy RD, et al. Interleukin 7 signaling in dendritic cells regulates the homeostatic proliferation and niche size of CD4+ T cells. Nat Immunol. 2009;10(2):149-57.

17. Gao J, Zhao L, Wan YY, Zhu B. Mechanism of Action of IL-7 and Its Potential Applications and Limitations in Cancer Immunotherapy. Int J Mol Sci. 2015;16(5):10267-80.

18. Shamim Z, Müller K, Svejgaard A, Poulsen LK, Bodtger U, Ryder L. Association between genetic polymorphisms in the human interleukin-7 receptor a-chain and inhalation allergy. Int $\mathrm{J}$ Immunogenet. 2007;34(3):149-51.

19. Hoffjan S, Beygo J, Akkad DA, Parwez Q, Petrasch-Parwez E, Epplen JT. Analysis of variation in the IL7RA and IL2RA genes in atopic dermatitis. J Dermatol Sci. 2009;55(2):138-40.

20. Heufler C, Topar G, Grasseger A, Stanzl U, Koch F, Romani N, et al. Interleukin 7 is produced by murine and human keratinocytes. J Exp Med. 1993;178(3):1109-14.

21. Yamada N, Wakugawa M, Kuwata S, Nakagawa $H$, Tamaki K. Changes in eosinophil and leukocyte infiltration and expression of IL- 6 and IL-7 messenger RNA in mite allergen patch test reactions in atopic dermatitis. J allergy Clin Immunol. 1996;98(6):201-S6.

22. AAAAI/ACAAI Joint Task Force Practice Parameters: Published Practice Parameters in Alphabetical Order [cited 2022 January 2]. Available from: https://www.allergyparameters.org/published-practiceparameters-guidelines/alphabetical-listing/.

23. Olivier J, May WL, Bell ML. Relative effect sizes for measures of risk. Communications in Statistics Theory and Methods. 2017;46(14):6774-81.

24. Shang H, Cao XL, Wan YJ, Meng J, Guo LH. IL-4 Gene Polymorphism May Contribute to an Increased Risk of Atopic Dermatitis in Children. Disease markers. 2016;2016:1021942.

25. Liang J, Liu Y, Xue R, Chen L, Chen H, Shao L, et al. Interleukin $4-590 \mathrm{C} / \mathrm{T}$ (rs2243250)Polymorphism Is Associated With Increased Risk of Atopic Dermatitis: Meta-Analysis of Case-Control Studies. Dermatitis: contact, atopic, occupational, drug. 2017;28(2):144-51.

26. Gleń J, Trzeciak M, Sobjanek M, Bandurski T, Wilkowska A, Nedoszytko B, et al.Interleukin-13 promoter gene polymorphism $-1112 \mathrm{C} / \mathrm{T}$ is associated with atopic dermatitis in Polish patients. Acta dermatovenerologica Croatica: ADC. 2012;20(4):231-8.

27. Shirkani A, Mansouri A, Farid Hosseini R, Jabbari Azad F, Alsadat Mahmoudian R,Montazer M, et al. The Role of Interleukin-4 and 13 Gene Polymorphisms in Allergic Rhinitis: A Case Control Study. 
Reports of biochemistry \& molecular biology. 2019;8(2):111-8.

28. Chen ML, Zhao H, Huang QP, Xie ZF. Single nucleotide polymorphisms of IL-13 and CD14 genes in allergic rhinitis: a meta-analysis. European archives of oto-rhino-laryngology:official journal of the European Federation of Oto-Rhino-Laryngological Societies(EUFOS) : affiliated with the German Society for Oto-Rhino-Laryngology - Head and Neck Surgery. 2018;275(6):1491-500.

29. Sinha S, Singh J, Jindal SK. Association of interleukin 7 receptor (rs1494555 and rs6897932) gene polymorphisms with asthma in a north Indian population. Allergy\& rhinology (Providence, RI). 2015;6(3):168-76.

30. Uehira M, Matsuda H, Hikita I, Sakata T, Fujiwara H, Nishimoto H. The development of dermatitis infiltrated by $ү \delta$ T cells in IL-7 transgenic mice. International immunology. 1993;5(12):1619-27.

31. Graham MT, Andorf S, Spergel JM, Chatila TA, Nadeau KC. Temporal Regulation by Innate Type 2 Cytokines in Food Allergies. Current allergy and asthma reports. 2016;16(10):75.

32. Yeon SM, Halim L, Chandele A, Perry CJ, Kim SH, Kim SU, et al. IL-7 plays a critical role for the homeostasis of allergen-specific memory CD4 T cells in the lung and airways.Scientific reports. 2017;7(1):11155.

33. Kelly EA, Koziol-White CJ, Clay KJ, Liu LY, Bates ME, Bertics PJ, et al. Potential contribution of IL-7 to allergen-induced eosinophilic airway inflammation in asthma.Journal of immunology (Baltimore, Md: 1950). 2009;182(3):1404-10.

34. Lundström W, Fewkes NM, Mackall CL, editors. IL-7 in human health and disease.Seminars in immunology; 2012: Elsevier.

35. Cianferoni A, Spergel J. The importance of TSLP in allergic disease and its role as a potential therapeutic target. Expert review of clinical immunology. 2014;10(11):1463-74.

36. Mai HL, Nguyen TVH, Bouchaud G, Henrio K, Cheminant MA, Magnan A, et al. Targeting the interleukin-7 receptor alpha by an anti-CD127 monoclonal antibody improves allergic airway inflammation in mice. Clinical and experimental allergy: journal of the British Society for Allergy and Clinical Immunology. 2020;50(7):824-34.

\section{Tables}

Table 1. Primer sequences of IL-7Ra gene SNPs at rs987106 and 6897932. 


\begin{tabular}{|rc|}
\hline IL-7Ra (rs:987106) & \\
\hline Reverse primer & 5' TGGTCACCCACCTAATTGTG 3' \\
\hline Forward primer & 5' GGAGACTGGGCCATACGATA 3' \\
\hline IL-7Ra (rs:6897932) & \\
\hline Reverse primer & 5'CCC ACA CAA TCA CCC TCT TTA T 3' \\
Forward primer & 5'CTT CAA GTG GCA GAT GCT CTG 3' \\
\hline
\end{tabular}

\begin{tabular}{|lll|}
\hline Step & $\begin{array}{l}\text { Temperature (o } \\
\text { C) }\end{array}$ & Time \\
\hline $\begin{array}{l}\text { Initial } \\
\text { Activation }\end{array}$ & $95^{\circ} \mathrm{C}$ & $15 \mathrm{mins}$ \\
\hline Denaturation & $95^{\circ} \mathrm{C}$ & $15 \mathrm{sec}$. \\
\hline Annealing & $60^{\circ} \mathrm{C}$ & $20 \mathrm{sec}$. \\
\hline Extension & $72^{\circ} \mathrm{C}$ & $20 \mathrm{sec}$. \\
\hline Melt & $60^{\circ} \mathrm{C}-95^{\circ} \mathrm{C}$ & $\begin{array}{l}90 \mathrm{sec} \text {. of pre melt on the first step and } 2 \mathrm{sec} \text {. for each step } \\
\text { afterward }\end{array}$ \\
\hline
\end{tabular}

Table 2. Temperature protocol for Corbett instrument HRM PCR

Table 3. Demographic characteristics of participants. 


\begin{tabular}{|c|c|c|c|}
\hline Characteristics & Patients group $(n=101)$ & $\begin{array}{l}\text { Control group } \\
(n=201)\end{array}$ & $\begin{array}{l}\mathrm{p}- \\
\text { value }\end{array}$ \\
\hline Years of age (Mean \pm SD) & $32 \pm 12.1$ & $32 \pm 12.5$ & $0.63^{*}$ \\
\hline \multicolumn{4}{|l|}{ Gender (n, \%) } \\
\hline Male & $37(36.6 \%)$ & $75(37.5 \%)$ & \multirow[t]{2}{*}{$0.73^{\#}$} \\
\hline Female & $64(63.4 \%)$ & $126(62.5 \%)$ & \\
\hline \multirow[t]{2}{*}{ Allergy type } & Allergic asthma: 58 (57.4\%) & \multirow[t]{2}{*}{--} & \\
\hline & Allergic rhinitis: 43 (42.6\%) & & \\
\hline $\mathrm{BMI}\left(\mathrm{Kg} / \mathrm{m}^{2}\right)$ & $23.2 \pm 1.9$ & $23.7 \pm 2.1$ & \\
\hline Total lgE serum levels (IU/mL) & $2651.7 \pm 166.3$ & $146.1 \pm 22.4$ & \\
\hline \multicolumn{3}{|l|}{$\left(10^{3} / \mu \mathrm{l}\right.$, Mean \pm SD $)$} & \\
\hline $\begin{array}{l}\text { Eosinophil count } \\
\left(10^{3} / \mu \mathrm{l}, \text { Mean } \pm \text { SD }\right)\end{array}$ & $6.2 \pm 1.8$ & \multicolumn{2}{|l|}{$0.6 \pm 0.2$} \\
\hline $\begin{array}{l}\text { Mast cell count }\left(10^{3} / \mu \mathrm{l}, \text { Mean } \pm\right. \\
\text { SD) }\end{array}$ & $2.1 \pm 0.8$ & \multicolumn{2}{|l|}{-- } \\
\hline Duration of Asthma (years) & $\begin{array}{l}8.4 \pm 3.2 \text { (in asthma } \\
\text { subgroup) }\end{array}$ & \multicolumn{2}{|l|}{-- } \\
\hline \multirow[t]{2}{*}{ Family History } & Yes: 29 (28.7\%) & \multicolumn{2}{|l|}{ Yes: 4 (1.9\%) } \\
\hline & No: 72 (71.3\%) & \multicolumn{2}{|l|}{ No: 197 (98.1\%) } \\
\hline Smoking & Yes: 41 (40.6\%) & \multicolumn{2}{|l|}{ Yes: 86 (42.7\%) } \\
\hline (Current or history) & No: 60 (59.4\%) & \multicolumn{2}{|l|}{ No: 115 (57.3\%) } \\
\hline \multirow[t]{2}{*}{ COPD } & Yes: 18 (17.9\%) & \multicolumn{2}{|l|}{ Yes: 3 (1.5\%) } \\
\hline & No: 83 (82.1\%) & \multicolumn{2}{|l|}{ No: 198 (98.5\%) } \\
\hline \multicolumn{4}{|l|}{ *: Calculated using paired t-test. } \\
\hline \multicolumn{4}{|c|}{ \#: Calculated using Pearson's chi-squared test. } \\
\hline \multicolumn{4}{|c|}{$\begin{array}{l}\text { SD: Standard Deviation, BMI: Body Mass Index, IU: International Unit, mL: Milli Liter, } \mu \text { l: MicroLiter, } \\
\text { WBC: White Blood Cells, COPD: Chronic Obstructive Pulmonary Disease }\end{array}$} \\
\hline
\end{tabular}


Table 4. Distribution of genotypes and alleles for SNP rs6897932 among patients and control groups.

\begin{tabular}{|c|c|c|c|c|}
\hline Genotype (n, \%) & Patients group & Control group & Odds Ratio (OR) * & $p$ value $^{\dagger}$ \\
\hline $\mathrm{CC}$ & 47 (46.5\%) & $147(73.1 \%)$ & - & $<0.001$ \\
\hline CT & $31(30.7 \%)$ & $54(26.9 \%)$ & - & \\
\hline TT & $23(22.8 \%)$ & $0(0.0 \%)$ & - & \\
\hline \multicolumn{5}{|l|}{ Allele (n, \%) } \\
\hline C & $47(46.5 \%)$ & $147(73.1 \%)$ & \multirow[t]{2}{*}{$3.13(1.90-5.16)$} & \multirow[t]{2}{*}{$<0.0001$} \\
\hline $\mathrm{T}$ & $54(53.5 \%)$ & $54(26.9 \%)$ & & \\
\hline \multicolumn{5}{|c|}{ *: 95\% Cl calculated using Woolf method. } \\
\hline
\end{tabular}

Table 5. Distribution of genotypes and alleles for SNP rs987106 among patients and control groups

\begin{tabular}{|c|c|c|c|c|}
\hline Genotype (n, \%) & Patients group & Control group & Odds Ratio (OR) * & p value ${ }^{\dagger}$ \\
\hline AA & $36(35.6 \%)$ & $138(68.7 \%)$ & - & $<0.001$ \\
\hline AT & $40(39.6 \%)$ & 40 (19.9\%) & - & \\
\hline TT & $25(24.8 \%)$ & $23(11.4 \%)$ & - & \\
\hline \multicolumn{5}{|l|}{ Allele (n, \%) } \\
\hline $\mathrm{T}$ & $65(64.4 \%)$ & $63(31.3 \%)$ & \multirow[t]{2}{*}{$3.95(2.39-6.55)$} & \multirow[t]{2}{*}{$<0.0001$} \\
\hline$A$ & $36(35.6 \%)$ & 138 (68.7\%) & & \\
\hline $\begin{array}{l}\text { *: } 95 \% \mathrm{Cl} \text { calcula } \\
\text { †: Calculated usi }\end{array}$ & $\begin{array}{l}\text { ed using Woolf } m \\
\text { g Pearson's chi-s }\end{array}$ & $\begin{array}{l}\text { ethod. } \\
\text { guared test. }\end{array}$ & & \\
\hline
\end{tabular}

